調查報告

\title{
情報記録手法之記憶定着·理解度の関係についての実験報告 〜手書き記録時とキ一ボード記録時の差異について〜
}

\section{A study on recording tools affecting memory and understanding}

$\sim$ A comparison between handwriting and keyboard input

\author{
曽根原士郎*, 齋藤敦子 \\ Shiro SONEHARA ${ }^{*}$, Atsuko SAITO
}

コクヨ株式会社

KOKUYOCo.,Ltd

干108-8710 東京都港区港南 1-8-35

一般的に、手書きでの情報記録手段は、教育現場において学習・記憶・理解の効果を高めると言われ ている。しかし、近年のビジネス現場ではパソコンへのキーボード入力が主流であり、特に若いビジ ネスワーカーはそれらデジタルツールを巧みに使いこなしながら、効率的に業務を行っている。本実 験では手書き記録手法の良さを再認識すると同時に、これからのビジネスワーカーがデジタルツール を用いてさらに生産性を高めていく可能性が示唆された。

In general, on educational situations it is said that handwriting will improve the effect of memory and understanding more than keyboard input. But recently, the keyboard input is the main current in business scenes and business workers skillfully master digital tool, so as to work efficiently. In this study we reconfirm the effect of handwriting, and suggest possibility that business workers in the future will improve the productivity with those digital tools.

キーワード: 手書き記録、キーボード入力記録、記憶、理解、ビジネススキル

Keyword: handwriting, keyboard input, memory, understanding, Business Skills

\section{1. はじめに}

これまでも手書き記録手法とキーボード入 力記録手法の差異による記憶定着への影響 に関する研究は各方面で行われてきたが、 その多くは学童や学生を中心としたものであ り、今後のビジネスマン、ビジネスシーン視点 での変化の傾向、兆候に着目した実験はあ まり例を見ない。しかし近年、オフィスのパソ コン環境は 1 人 1 台が一般的となり、多くの業 務がキーボード入力で行われる様になった 事から、ワーカーのノートや手帳と言った手 書き記録ツールの活用目的やシーン、期待
効果にも変化が生じつつあると考えられる。 今回、入社 8 か月を経て基本的ビジネススキ ルと現場経験を習得した直後の社員を将来 の対象ビジネスマンと想定して、記録手法別 に各ビジネスシーンを想定した情報の記録と、 その記憶定着率や理解度に差異が生じるの かを実験した。

\section{2. 実験方法}

2.1. 実験参加者

入社 8 力月後の社員 20 名 


\section{2. 実験装置}

Anoto デジタルペン・ペーパー、ノート PC(素材再生用、参加者利用用)、スピーカー (素材再生用 PC に接続)、タイマー、ビデオカ 妨

\section{3. 呈示刺激}

第一部素材:参加者間に前提知識の差を 生じさせない内容で、非常に単純な $5 \mathrm{~W} 1 \mathrm{H}$ の 記憶を確認する事を目的とした、動物が主人 公の架空の話(2 分程度)。第二部素材:業務 シーンを想定し、構造化された話を記憶・確 認する目的として、消防署をモデルとした組 織構造と職務内容の説明(3 分程度)。第三部 素材:業務上で最も頻繁に想定される打合せ 議事の記録や他者から口頭指示、説明を受 けるシーンでの記憶・内容理解の確認を目的 とした、大学教授による企業の戦略要素や組 織論についての講演(12 分程度)。

\section{3. 手続き}

参加者の日常業務でのノート利用頻度や IT リテラシー等を事前に確認し、そのスキル 別に3つの会議室に振り分けた後、各部屋単 位に「手書きでメモを取るチーム」(8 名:日常 的にノ一ト利用率が高い、以下、手書きチー ム)、「PCでメモを取るチーム」(8 名:Powerpoint スキルが高い、以下、PC チー 么)、「何も記録媒体を与えないチーム」(4名、 以下、媒体無しチーム)とした。

各素材は音声データ化し、各会議室で個 別に再生用 PC で第一部から第三部まで順 番に再生しながら参加者に聞かせた。その 際、手書きチーム」は利用者用 PC を起動さ せず、Anoto デジタルペンとペーパーを利用 して内容を手書き記録させた。「PC チーム」 は利用者用 PC 上に Powerpoint でメモファイ ル(白紙)を準備し内容をキーボード入力記録 させた。「媒体無しチーム」は、ただ着席し利 用者使用 PC も起動せず素材音声を聞かせ た。

第三部設問終了後、干涉テストとして百マ ス計算問題(7 分)を紙で実施し、その後、全員
が利用者用 PC に準備された素材別設問付 き解答ファイルを指示に従って順に起動し、 解答を作成した。

第一部素材の設問は動物名や描写、 $5 \mathrm{~W} 1 \mathrm{H}$ に関係する単純な単語記憶を確認す る内容(第一部単語)を、第二部素材の設問は 各組織の名称と職務の内容を答えさせる単 語記憶(第二部単語)と組織を階層図で答えさ せる構造確認(第二部構造)を、第三部素材の 設問は講演内に含まれる重要語句にあたる 単語抽出(第三部抽出)と各センテンス単位の 内容理解を確認する記述式解答、及び上司 への全体要旨の報告文作成(第三部理解)と した。その際、第一部・第二部の設問解答で は一切メモや記録は見ずに行う事にし、第三 部設問解答のみ各メモや記録を参照して良 い事しした。(「媒体無しチーム」ではそもそも メモ・記録を行わない為、第三部についても 第一部・第二部と同様の条件とした。）

\section{4. 実験結果}

実験結果は次に示すようなものであった。 4.1. 設問別の正答率

記録手法チーム別の各設問解答の平均点 を比較した結果、第一部設問解答では「媒体 無しチーム」が最も成績が高く、以降は全て 「PCチーム」の成績が高かった。

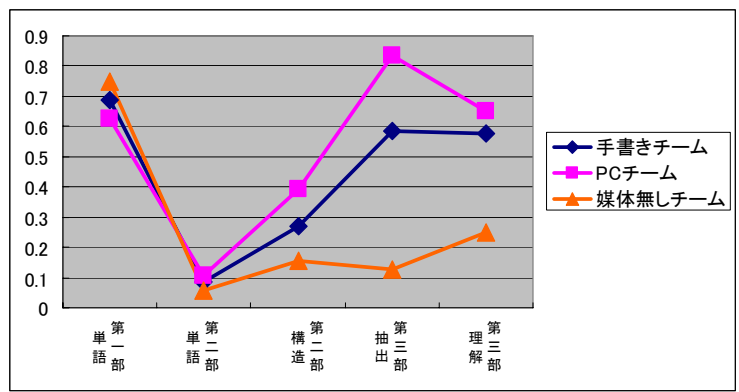

図 1:解答別の平均点推移

当初の仮説では第二部の構造確認や第三 部理解確認の設問においては、「手書きチー ム」が聞き取り内容を描画化する自由度(簡単 に構造を図化して書き取る事ができる)の点 から、記憶定着率的にも効率が良い手法しし て優位になると想定していたが、結果として 「手書きチーム」の成績は第二部単語以降、 
他の手法を上回る事がなかった(図 1)。又、第 三部単語抽出の設問では、「手書きチーム」 と「PC チーム」はメモを見ながら回答するとし た事によって、媒体無しチーム」との差が大 きく開いた。

\section{2. 平均値の差の検定}

統計分析の結果、第三部設問の単語抽出 設問解答において、「手書きチーム」と「PCチ 一ム」との間で平均值の差の $\mathrm{t}$ 検定を行った ところ、 $\mathrm{t}=-2.51(\mathrm{df}=14)$ となり、5\%水準で有意で あった。

\section{3. 正解文字数の比較}

「手書きチーム」と「PC チーム」のメモ記録 (入力)文字数とその内に含まれた正解解答 部分の文字数を比較した結果、第三部に大 きな差が見られた(図 2)。しかし、同文字数を その比率で比較した場合は逆に差異は見ら れなかった(図 3)。

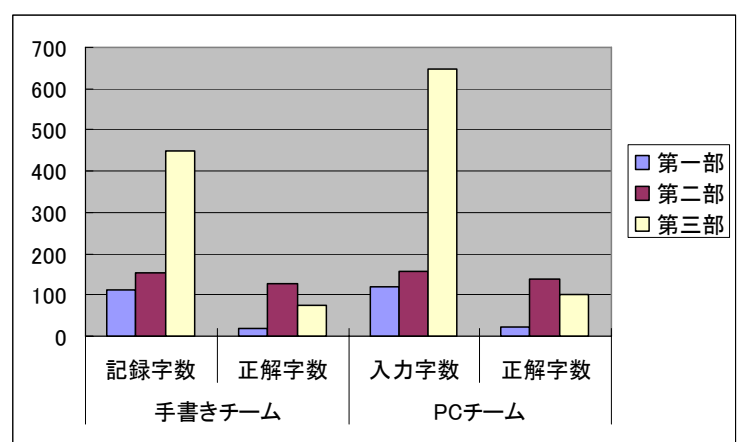

図 2:メモ記録字数とその内の正解字数比較

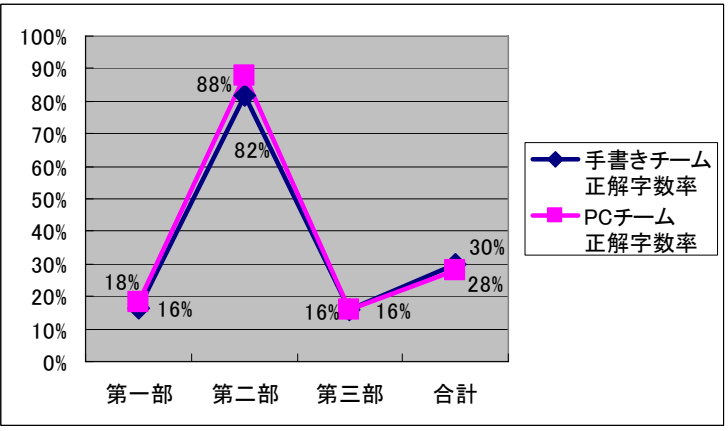

図 3:入乇記録字数内の正解字数の比率比較

\section{4. 得点のレンジ}

「手書きチーム」と「PC チーム」の参加者 個々の得点と各所属チームの平均点との差
を見た場合、「手書きチーム」では最高得点 者と最低得点者の得点差は土6 点の範囲(図 4)にあるのに対して、「PC チーム」内での同 得点差は土8.6 点となった(図5)。又、「媒体無 しチーム」での同得点差は土7.25 点であった。 「媒体無しチーム」は元々参加者が 4 名と少 ない上に、高得点と低得点に 2 名ずつ分れ てしまっている為、データ、平均点共に参考 程度とした。

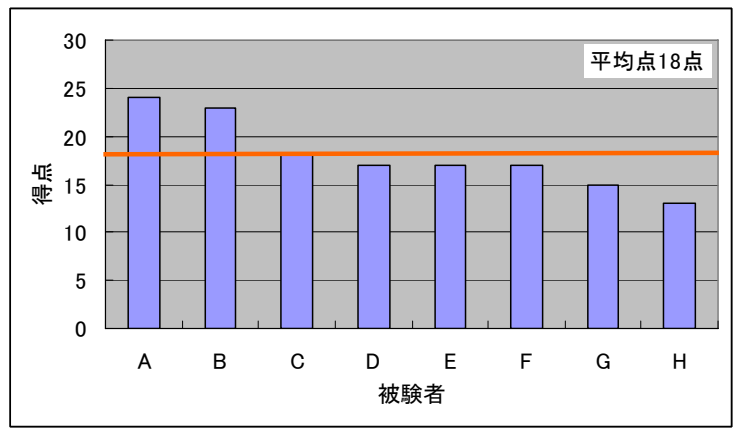

図 4:手書きチームの各自得点と平均点の差

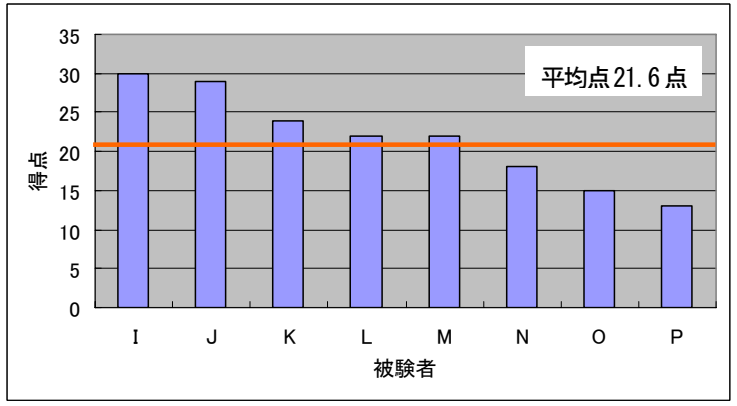

図 5:PCチームの各自得点と平均点の差

\section{5. 考察}

\section{1.単純な設問}

図 1 の結果からら、第一部素材では「媒体無 しチーム」が記録ツールの干渉を受けず集中 できた事により、記憶定着率が高まったと考 えられる。元々第一部素材は本文 325 文字 程度、内正解部分の字数は 40 文字程度で構 成される単純なものだった。しかし「手書きチ 一ム」は初めて手にする「Anoto デジタルペ ン・ペーパーと利用ルール」に、「PC チーム」 は準備された「自分の物ではないPC」と「仛 ファイル(Powerpoint ファイル)」操作に意識が 分散していたと想定でき、統制環境の差異と 考えられる。 


\section{2.複雑な設問}

同じく図 1 の結果から、実験が進むにつれ 「PC チーム」の集中力・記憶定着率が高まっ た可能性が考えられる。今回の参加者は入 社 1 年次の一般社員であったにもかかわらず、 「メモファイル(Powerpoint ファイル)」と同実験 ビデオで確認したところ、「PCチーム」での第 二部、第三部の平均文字入力速度は 50〜 55 字(変換後字数)/分と考えられ、ヒアリング・メ モ入力中は充分に集中できていたと考えら れる。

特に図 2 に見られる様に、第三部でのキー ボード入力文字数は「手書きチーム」の 1.4 倍 にも達しており、その集中状態での聴写力 (聞き取り書き写す/入力する能力)が高まった 事によって第二部構造や三部単語抽出の得 点差が生じたと考えられる。

\section{3. 記録文字数と解答文字数}

しかし図 3 の結果からは、記録/入力文字 数とその中に含まれる正解部分の文字数の 比率は「手書きチーム」「PC チーム」の間で 差が見られない。この事から、聴写力は両于 一ム間に大きな差がない、若しくは聴写力は 記録手法に起因する記録量/スピードと相関 し一定の比率範囲に止まる傾向があると考え られる。言い換えれば、より多く記録できるか らと言って正解部分が飛躍的に多くなる事や、 記録できる量が少ないからと言って的確に正 解部分のみを記録する、といら傾向は見られ なかった。

\section{4. 単語記憶の正解率}

一方、同じ図 3 の結果から、第二部では 「手書きチーム」、「PC チーム」共にメモ記録 文字数に占める正解文字数率が非常に高い にもかかわらず、同単語記憶の設問正解率 が「媒体無しチーム」と変わらない程度であっ た事は、聴写力と単語の記憶定着率の間に 相関が無いとも考えられる。特にこの第二部 素材は 400 文字弱のコンテンツであったが、 所謂エピソード記憶化し難い組織名称や職 務内容の羅列で構成されていた為、聴写力
に基づく単語記録は正確になされていても、 その記銘や保持には至っていなかったと考 えられる。

逆に同構造設問解答では「PC チーム」、 「手書きチーム」共に「媒体無しチーム」を大 きく上回った事から、聴写力による全体俯瞰 された構造化と記憶定着率には相関性があ ると考えられる。

\section{5. 手書きの優位性(1)}

図 1 の結果から、第二部構造設問解答で は「PC チーム」に、当初仮説立てしていた 「手書きチーム」の優位性を上回る成果が見 られた。この両チームの第二部メモを添削・ 検討したところ、「手書きチーム」のメモの多く には、予想通り円や線で階層を表現した自然 な形での記録がみられた。しかし「PC チー ム」のメモ(Powerpoint ファイル)では、改行や スペース挿入、タブ機能等を使って工夫/苦 労しながら入力された形跡が多く見られ、そ れらの描画・操作ストレスが、逆に強い記憶 定着をもたらした可能性が考えられる。

\section{6. 入力スキル}

図4の結果から、「手書きチーム」内で得点 差が最も少なかった事は、「人の話を聞いて、 必要事項をノ一トに書きとめる」と言う基本動 作と記憶定着の訓練が同チーム内参加者間 に一定のレベルで存在していたと考えられる。 逆に図 5 で示した「PCチーム」内の下位得点 者 2 名のキーボード入力字数は、残り 6 名の 平均に対して 57\%程度であり、入力スピード・ スキルに関する訓練不足、差がそのまま得点、 記憶定着に影響を及ぼしていると考えられ る。

\section{7. 手書きの優位性(2)}

「手書きチーム」と「PCチーム」の第三部抽 出・理解の結果に限ってみた場合、それぞれ の図 1 平均点推移亡図 2 記録文字数を比較 すると図6の様な関連が見られる。前述の通 り第三部で両チームは記録した各自のメモを 見ながら解答作成を行ったが、その記録文字 
数をベースに平均点を見ると、「手書きチー ム」が少ない記録文字数にもかかわらず効率 的に得点を挙げたのに対し、「PCチーム」は 記録文字数の多さが、内容理解解答や上司 への報告書作成時に非効率性を招いたとも 考えられる。

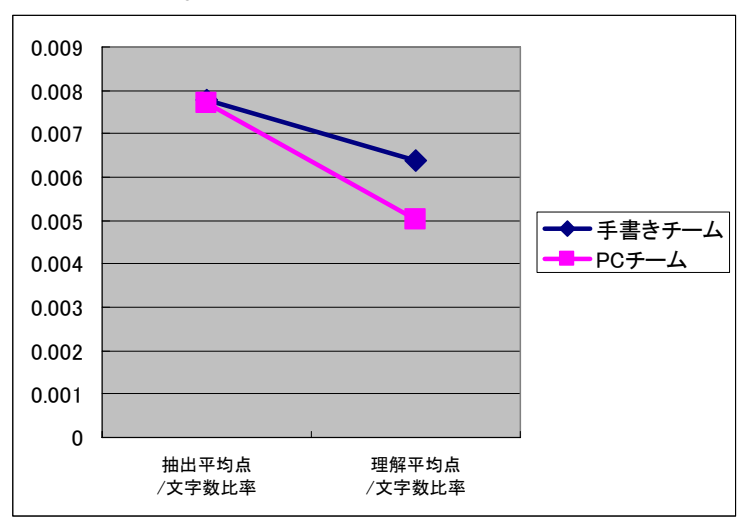

図 6:記録文字数に対する各平均点の比率 言い換えれば、均一なテキストによるメモ 記録の中では重要度や強弱、要素間の関係 性が見えず、見返しづらい構造となってしま ったが故に、解答作成に必要・適切な要素が 探し出せない状況になってしまっていたと考 えられる(図 7)。

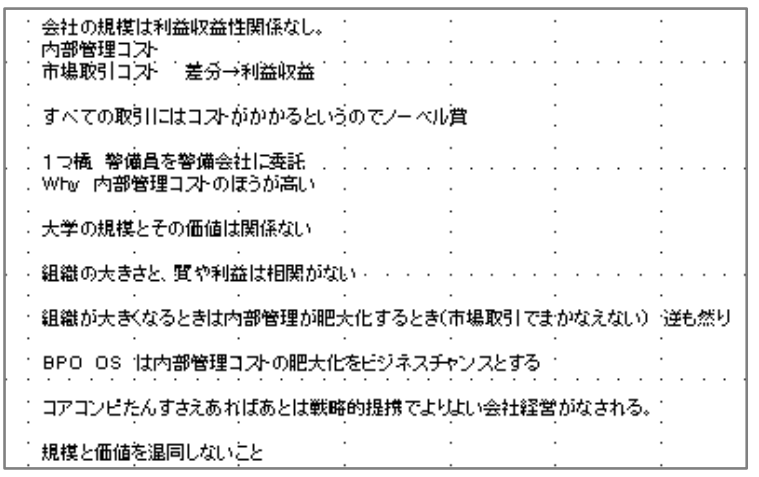

図 7:PC チーム得点上位者のメモファイル 逆に「手書きチーム」の得点上位者のメモ では、重要度や強弱に応じた文字サイズの 書き分けや丸で囲む、矢印で要素間の関係 を表す等の工夫が見られ、仛を見ただけで も、どの様な話の流れであったかが理解でき るものとなっていた(図8)。この点は考察5.3。 5.4.と合わせて考えると、手書きによる記録手 法を使った想起・再生では、単純な文字と文 字数だけでは無く、各種要素の識別や意図・ ニュアンス、階層化が自由な描画・形状表現 が可能で、非常に大きな効果・効用があると

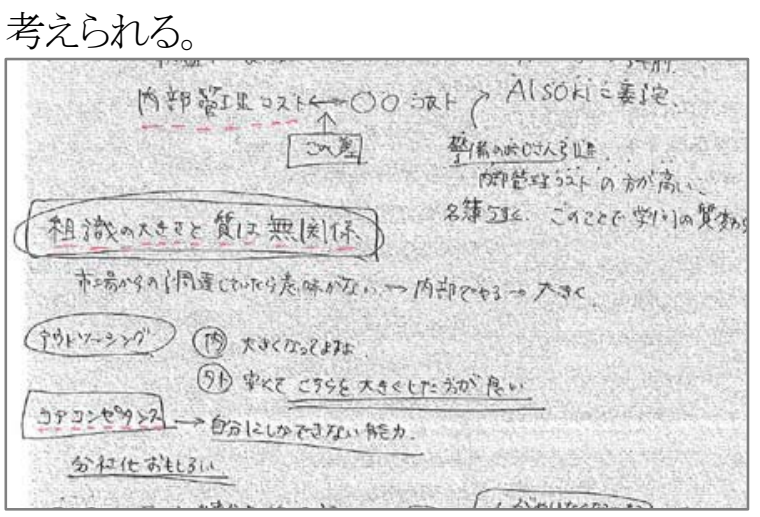

図 8:手書きチーム得点上位者のメモ

\section{8. メモの重要性}

第三部理解に関する設問解答(上司への 報告文作成)内容を添削・検討した結果、「手 書きチーム」、「PCチーム」では、同単語抽出 設問解答に見られた差以上の質の差は見ら れなかった。この事は、ヒアリング時の聴写力 による正確な各単語抽出能力と文意全体を 把握・理解し表現する能力は別であると考え られると同時に、同設問解答において「媒体 無しチーム」ではほとんど体をなさない状態 であった事からも、ある程度正しい文章をまと め上げる為には、その正確性を問わず、後か ら内容を想起・再生する為の何らかの意味あ る情報を書き留める/入力する事が非常に重 要だと考えられる。

\section{6. まとめ}

ビジネスシーンでは単純な $5 \mathrm{~W} 1 \mathrm{H}$ を中心と した情報にとどまらず、より高度で複雑な業 務情報の口頭指示・説明の記録・記憶が正確 且つ要点を押さえてスピーディーに行われる 事が求められる。この必然性への対処方法と して教育の現場で培われ訓練されてきた手 書き記録手法とそれをべースとした記憶定着 効果は疑うところではない。今回PCを使った 記録・記憶手法と合わせて、対象情報が複雑 になるほど、記録媒体を使わない場合との記 銘・保持・想起の差は明確であり、現実のビジ ネスマン、ビジネスシーンにおいても、業務 情報を「記憶にとどめる、理解する」為には 「(手書き/PC 問わず)記録する」事は必須で 
ある事が本実験結果からも見て取れる。

しかし同時に、今後の更なる PC の普及や 業務上での活用環境の拡大を通じてリテラシ 一、スキルが強化されてゆく事で、PC を使っ た記録手法は、その記憶定着や内容理解・ 文章化効果の点で従来の手書き記録手法を 上回る可能性が示唆されたとも考えられ、こ れ事は大きな発見であった。

今後は引き続き手書き手法の価值・効果の 研究を進めると同時に、考察 5.6.5 5.7.で述 べた様な、手書き記録手法の持つ特性を生 かしつつ効果的な記録・記憶(記銘・保持・想 起)を支援する、PC活用環境やシステムソフト ウェアを含めた仮説を構築し、その実現方法 や可能性、それらを用いた記録・記憶への効 果等の調査を検討・考察してゆく。

\section{7. 今後の課題}

(1)

各チームとも参加者数が少なく、事前にス クリーニングは行ったものの、参加者の特性 に強く依存している可能性が高かったと思わ れる。今後、本実験を検討する場合は参加者 数を増やすと同時に、同一人物への同質実 験で検証する方法を検討したい。

\section{(2)}

各種設問の内容と提示順序、時間配分、 音源データの再生速度や音量に更なる統 制・考慮が必要だったと感じる。又、今回実験 中の統制(記録媒体個々の不具合等)に若干 差が生じていた可能性があり、より正確な統 制の統一を検討したい。

\section{(3)}

各種設問設計と解答分析手法の精度を更 に高める必要があると感じた。特にビジネス シーンを想定した「理解度」確認に関する記 述解答とその解釈・分析について、次回は充 分に検討の時間を取り組み立てたい。
今後は記録媒体に、目的に対する効果を 仮説立てして設計した意匠を伴った場合の 手書き/キーボード入力記録手法の効果の差 異含めた検証も検討したい。

\section{謝辞}

実験にご協力頂きました皆様に感謝致しま す。

\section{参考文献}

1. 吉村宰、他:『「書く」ことへの態度及び習 慣と報告型作文の評価との関連につい て』、日本行動計量学会大会発表論文抄 録集(37)、56-57、2009

2. 鈴木慶子、他:『視写と聴写に関する基礎 調査(1)』、書写書道教育研究 23 号 11-20、2009

3. 大山典子、他:『デジタルノートテイキング に適した入力方法の研究 〜手書き入 力とキーボード入力の差をめぐって〜』、 情報処理学会第 70 回全国大会講演論 文集、"4-607"-"4-608"、2008

4. 上野賢太郎、他:『ノートテイキングにお ける手書きとワープロの差異の研究〜キ ーワードに注目した比較実験の視点か ら〜』、情報処理学会第 70 回全国大会 講演論文集、"4-609"-"4-610"、2008

5. 小川美沙都、他:『ノートテイキングにお ける手書きとワープロの質的な差に関す る検討(4)』〜講義内容の記憶と視点に 関する考察〜、情報処理学会第 70 回全 国大会講演論文集、"4-743"-"4-744"、 2008 